\title{
Индукция засухоустойчивости растений Triticum aestivum L. (пшеницы) разных агроэкологических групп эндофитными бактериями Bacillus subtilis
}

() О. В. Ласточкина ${ }^{1 *}$, Д. Р. Масленникова ${ }^{1}$, Д. Ю. Гаршина ${ }^{2}$

${ }^{1}$ Институт биохимии и генетики УФИЦ РАН

Россия, Республика Башкортостан, 450054 г. Уфра, проспект Октября, 71.

${ }^{2}$ Башкирский научно-исследовательский институт сельского хозяйства УФИЦ РАН Россия, Республика Башкортостан, 450059 г. Уфра, улица Рихарда Зорге, 19.

\section{*Email: oksanaibg@gmail.com}

Установлено, что важный вклад в вызываемую эндофитными бактериями B. subtilis 104 адаптацию и засухоустойчивость растений пшеницы - представителей степного Волжского (сорт Экада70) и лесостепного западносибирского (сорт Салават Юлаев) экотипов вносит способность этих бактерий регулировать состояние компонентов AsAGSH комплекса и стабилизировать окислительный статус в клетках растений при стрессе.

Ключевые слова: Triticum aestivum L., экотипы, засуха, бактерии-эндофиты, Bacillus subtilis, растительно-микробные взаимодействия, $\mathrm{H}_{2} \mathrm{O}_{2}$, МДA, AsA-GSH комплекс, индуцированная устойчивость.

Triticum aestivum L. (мягкая яровая пшеница) - наиболее распространенная в мире ценная зерновая продовольственная культура [1]. Доминирующим абиотическим стрессом, приводящим к снижению роста и продуктивности пшеницы, является засуха [2]. Применение стимулирующих рост растений эндофитных бактерий (PGPEB - Plant Growth-Promoting Endophytic Bacteria) Bacillus subtilis, способных активировать естественные защитные механизмы растений-хозяев, не вызывая негативного воздействия на них, окружающую среду и здоровье человека рассматривается как доступная, дешевая и экологически чистая биологическая стратегия улучшения адаптивного потенциала и урожайности растений в стрессовых условиях среды [2-4]. Одной из основных причин, сдерживающих в настоящее время разработку препаратов на основе бактерий-эндофитов является недостаток знаний о фундаментальных механизмах взаимодействия эндофитных $B$. subtilis с растениями в условиях дефицита влаги. Кроме того, возникают вопросы, связанные с тем, что эффективность одного и того же штамма $B$. subtilis может варьироваться в зависимости от многих фракторов, включая спектр синтезируемых штаммами соединений, вид растений, их эколого-географическое происхождение, сортовые особенности, виды стрессов, которым подвергаются растения в период вегетации и мн. др. [2,4]. Ранее нами было выявлено, что сорта пшеницы, различающиеся по стратегии адаптации к засухе и принадлежащие к разным агроэкологическим группам (экотипам) (а именно, лесостепному западносибирскому и степному Волжскому), демонстрируют разную реакцию на инокуляцию одним и тем же эндофитным штаммом B. subtilis 10-4 при одном и том же стрессе (засуха) на ранних этапах онтогенеза [4]. Так, показано, что предпосевная обработка B. subtilis 10-4 [4] оказывает более заметный протекторный эффрект на растения пшеницы степного Волжского экотипа в условиях засухи, как на уровне клеток, так и целого организма, тогда как для растений лесостепного западносибирского экотипа такого же защитного эфффекта на 
рост не наблюдалось, а на уровне клеток защита была на более низком уровне. Также было выявлено, что такой характер влияния $B$. subtilis 10-4 на рост растений пшеницы коррелирует с накоплением эндогенной салициловой кислоты (СК) в них и запуском СК-зависимых сигнальных путей.

В настоящей работе с использованием классических и современных фиииологобиохимических методов исследовано влияние предпосевной инокуляции эндофитными B. subtilis (штамм 10-4, рег. номер в ВКПМ В-12988) на содержание пероксида водорода $\left(\mathrm{H}_{2} \mathrm{O}_{2}\right)$ [5], уровень перекисного окисления липидов (МДА) [6], а также состояние компонентов аскорбат-глутатионового (AsA-GSH) комплекса (аскорбат (AsA), восстановленный глутатион (GSH), окисленный глутатион (GSSG), аскорбат пероксидаза (APX), глутатион редуктаза (GR)) [7] в проростках яровой мягкой пшеницы - представителях степного Волжского (сорт Экада70, засухоустойчивый) и лесостепного западносибирского (сорт Салават Юлаев, засуховосприимчивый) экотипов в нормальных условиях произрастания и при засухе (12\% ПЭГ-6000). Семена перед посевом стерилизовались 96\% этанолом, замачивались в течение 1 часа в растворах B. subtilis 10-4 (10 $\mathrm{KOE} / \mathrm{Mл)}$ или воде [4]. Обработанные семена проращивались на фильтровальной бумаге, смоченной дист. водой в течение трех-четырех суток (16-часовой световой фотопериод, 15 клк, 22-24 $\left.{ }^{\circ} \mathrm{C}\right)$, пересаживались в растворы с 12\% ПЭГ-6000 или воду и через разные промежутки времени проростки использовались для анализов. В рисунках приведены значения трех повторений \pm SEM. Разные буквы указывают на значительную разницу между средними на уровне вероятности $p<0.05$.

Результаты показали, что воздействие засухи приводило к накоплению $\mathrm{H}_{2} \mathrm{O}_{2}(130-140 \%$ от контроля) в корнях 4-сут проростков сорта Экада70 (Рис. 1А) с пиком на 1 час воздействия стресса и вызывало транзитное почти трехкратное накопление (регистрируемое на 30 минутах эксперимента) в корнях проростков сорта Салават Юлаев (Рис. 1Б), что коррелировало с накоплением МДА в растениях обоих сортов (Рис. 1В). Предобработка B. subtilis 10-4 способствовала стабилизации состояния целостности мембранных структур при стрессе (Рис. 1).

Анализ важнейших неферментативных восстановителей клеток AsA и GSH, играющих ключевую роль в реализации фризиологических процессов растительной клетки, а также в регуляции редокс-метаболизма, показал, что растения сортов Экада70 и Салават Юлаев различаются по уровню их содержания. Так, в нормальных условиях произрастания проростки пшеницы сорта Экада70 характеризовались незначительным, но достоверно большим (124 \%) содержанием GSH (Рис. 2A) по сравнению с проростками сорта Салават Юлаев (Рис. 2Б), которые, при этом, содержали значительно больше AsA (160 \%), что очевидно обусловлено их сортовыми особенностями. Предобработка B. subtilis 10-4 приводила к дополнительному накоплению AsA в растениях обоих copтов, при этом наибольшее накопление на протяжении всего опыта наблюдалось у сорта Экада70 (примерно 150 \% от контроля). Уровень GSH у растений предобработанных B. subtilis 10-4 существенно не изменялся, хотя и наблюдалось небольшое его накопление. Важно отметить, что уровень GSSG в растениях обоих сортов, инокулированных B. subtilis 10-4, оставался неизменным, что свидетельствует об отсутствии негативного действия бактериальной обработки на физиологическое состояние растений.

Обнаружено, что растения сорта Салават Юлаев были более восприимчивы к воздействию засухи, о чем свидетельствует резкое падение содержания AsA более чем в 3 раза на протяжении всего опыта и практически двухкратное снижение уровня GSH, которое коррелирует с таким же по уровню накоплением GSSG (Рис. 2Б). Оценка содержания AsA и GSH в условиях засухи у пшеницы Экада70 демонстрирует заявленную засухоустойчивость данного сорта - падение содержания AsA составляет около $20 \%$ относительно уровня контроля, при этом глутатионовая система реагирует на стресс ярче, о чем свидетельствует в среднем полуторакратное падение содержания GSH на 
протяжении всего времени действия стресса и двукратное накопление GSSG к 1 часу воздействия стресса и заметное снижение его уровня к 5 часам воздействия стресса (Рис. 2A), что может говорить о том, что этот сорт может значительно легче адаптировать к воздействию засухи. Это указывает на то, что одну из ключевых ролей в реализации засухоустойчивости у растений сортов Салават Юлаев и Экада70 играют AsA и $\mathrm{GSH}$, соответственно.

(A)

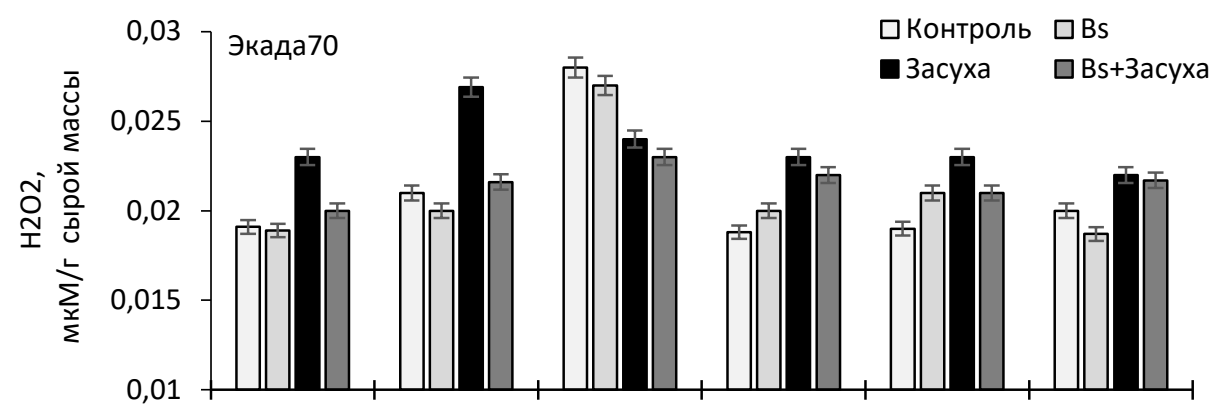

(Б)

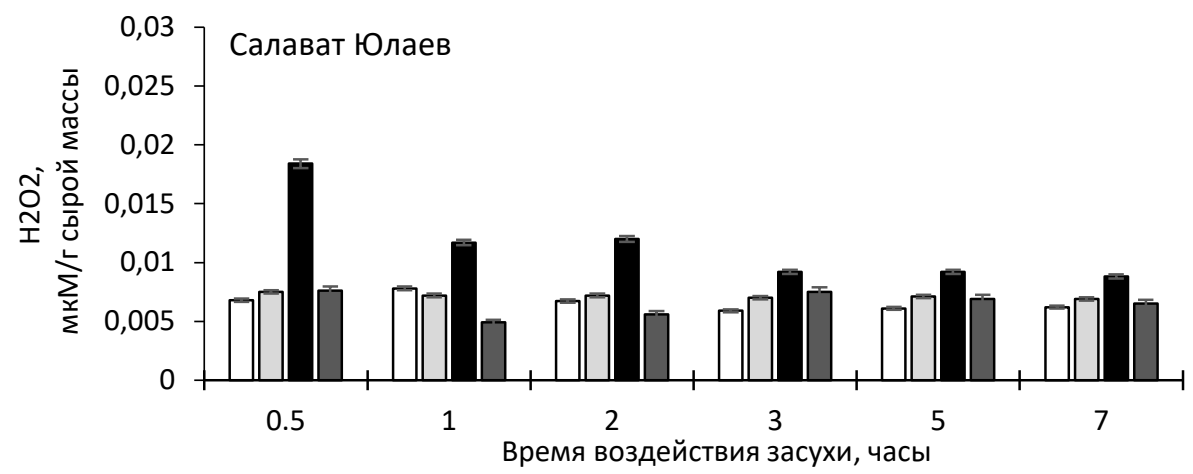

(B)

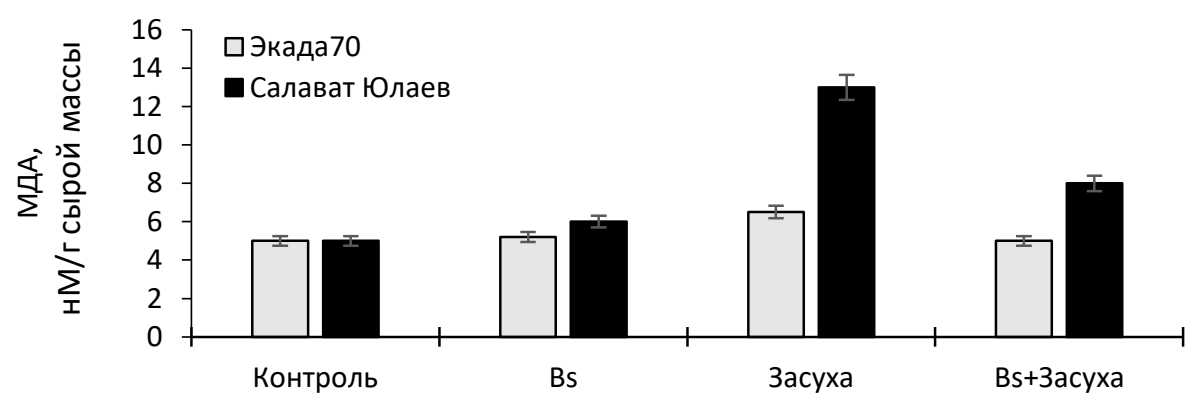

Рис. 1. Влияние предобработки B. subtilis 10-4 (Bs) на содержание пероксида водорода $\left(\mathrm{H}_{2} \mathrm{O}_{2}\right)(\mathrm{A}$, Б) и уровень перекисного окисления липидов (МДА) (B) в проростках яровой пшеницы сортов Экада 70 (степной Волжский экотип, засухоустойчивый) и Салават Юлаев (лесостепной западносибирский экотип, засуховосприимчивый) в норме и при засухе. 
(A)

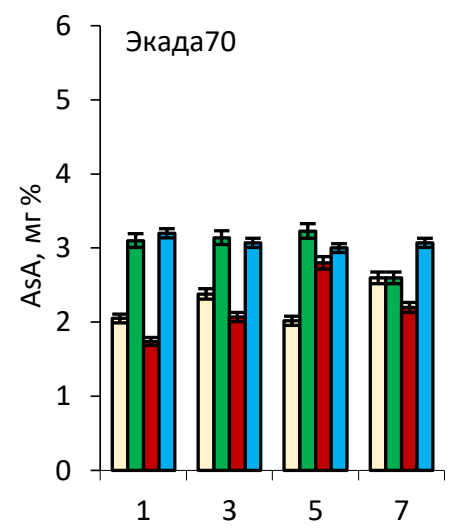

(Б)

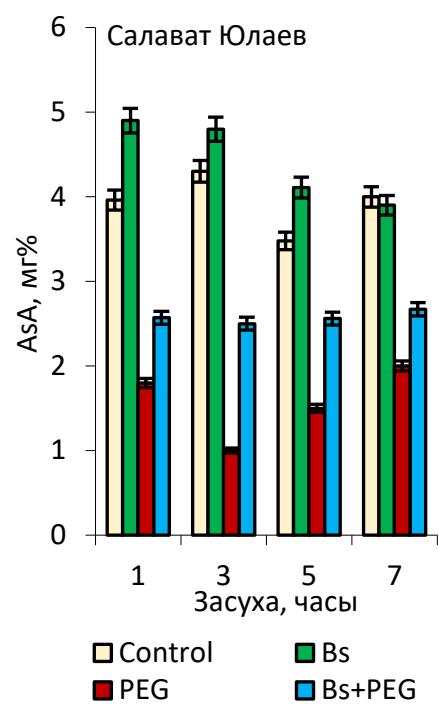

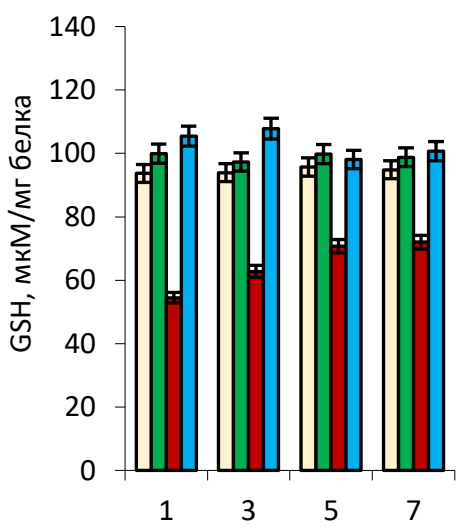
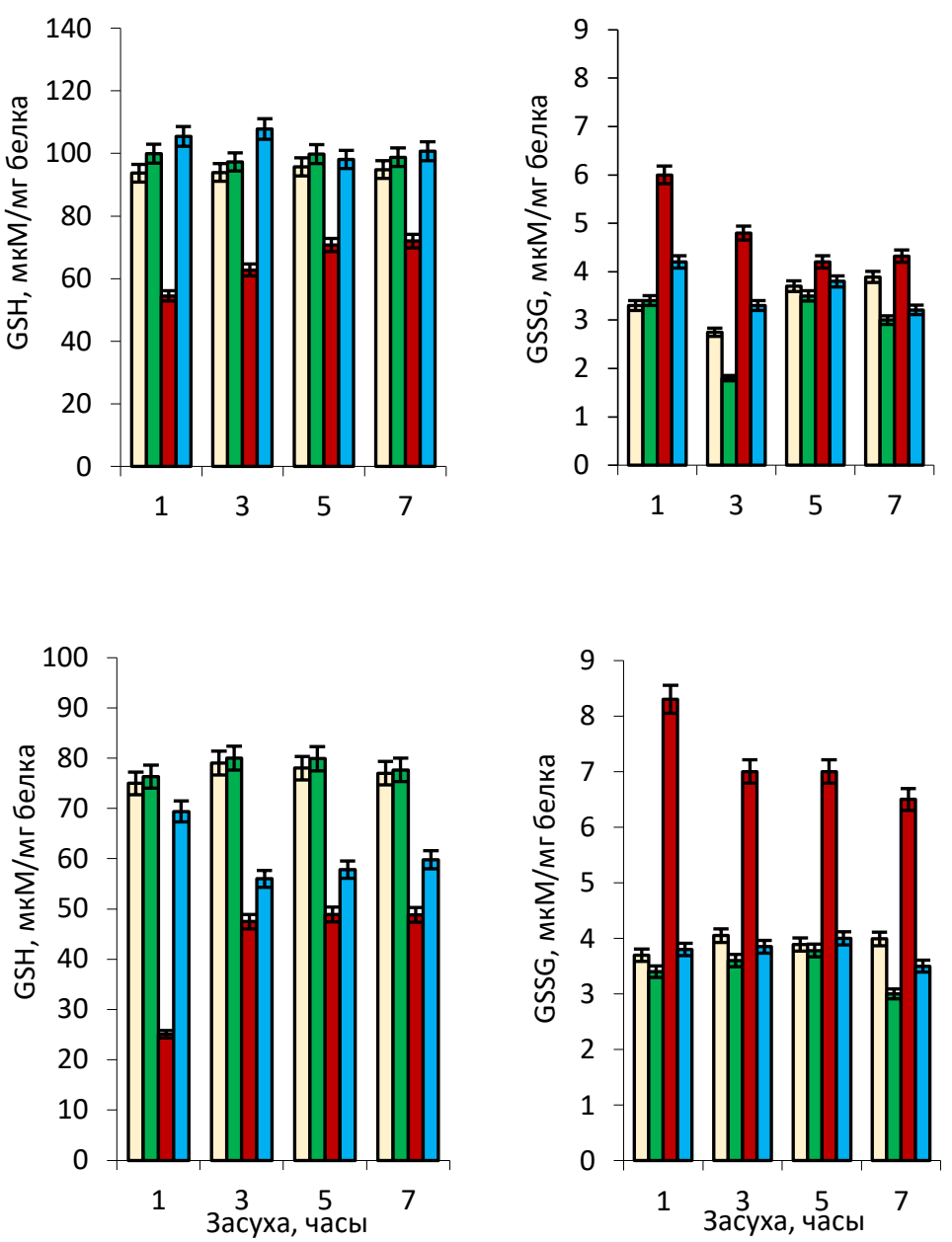

Рис. 2. Влияние предобработки B. subtilis 10-4 (Bs) на содержание некоторых неферментативных антиоксидантов (аскорбата - AsA, восстановленного глутатиона - GSH, окисленного глутатиона - GSSG) в проростках яровой пшеницы сортов Экада 70 (степной Волжский экотип, засухоустойчивый сорт) (А) и Салават Юлаев (лесостепной западносибирский экотип, засуховосприимчивый сорт) (Б) в норме (Control) и при засухе (PEG).

Предобработка B. subtilis 10-4 не предотвращала стресс-индуцированное падение AsA в растениях сорта Салават Юлаев (Рис. 2Б), но способствовала поддержанию повышенного его уровня (130-250\%) в сравнении с контрольными (небактеризованными) и стрессированными растениями. При этом наблюдалась стабилизация глутатионового статуса, содержание GSH на 1 часе воздействия стресса было достоверно выше контрольного, далее его уровень был выше стрессового, но не дотягивал до контрольного. При анализе антиоксидантов в растениях сорта Экада70 было обнаружено, что предобработка $B$. subtilis 10-4 приводит к дополнительному (до 150\%) накоплению AsA в них. При этом наблюдалось полное восстановление до контрольных значений стрессиндуцированного дисбаланса GSH. В растениях обоих сортов предобработка B. subtilis 10-4 стабилизировала содержание GSSG до уровня контроля в условиях засухи (Рис. 2А,Б), что говорит об эффективности бактериальной обработки и демонстрирует выраженный защитный эффрект.

Ключевую роль в стабильной работе AsA-GSH цикла, а также в стабилизации стрессиндуцированного дисбаланса составляющих про-/антиоксидантной систем отводят 
ферментам APX и GR. В ходе работы было обнаружено, что засуха приводила к сильнейшей активации этих ферментов, при этом у растений сорта Салават Юлаев амплитуда ответа была выше, чем у растений сорта Экада70 (Рис. ЗА,Б), такая работа фрерментов находила свое отражение также в ходе оценки содержания $\mathrm{H}_{2} \mathrm{O}_{2}$, МДА (Рис. 1), AsA и GSH (Рис. 2). Предобработка B. subtilis 10-4 в условиях стресса приводила к снижению активности APX и GR в растениях сорта Салават Юлаев. Тогда как у растений сорта Экада70 наблюдалось меньшее снижение (на $115-120 \%$ от контрольного) активности APX и дополнительная активация GR (на 125-130\%).

(A)

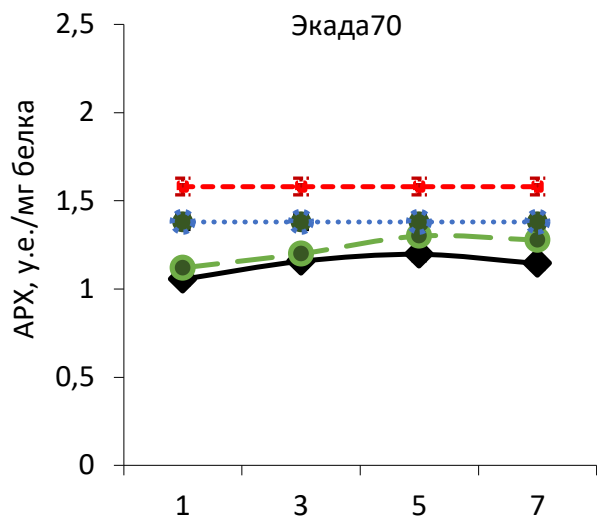

(Б)

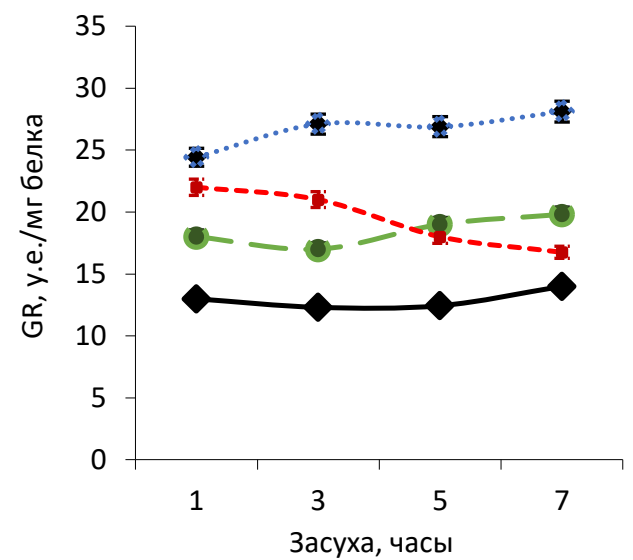

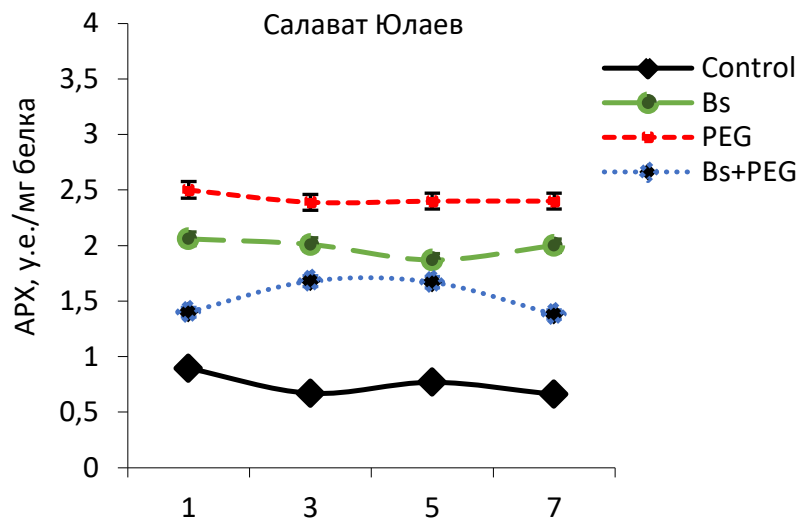

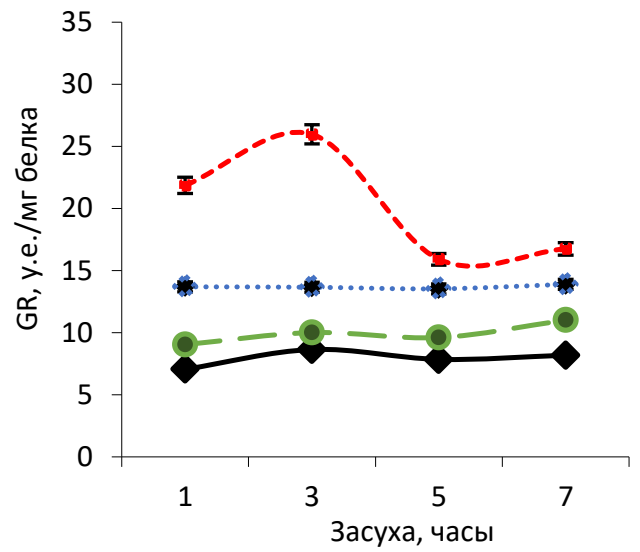

Рис. 3. Влияние предобработки $B$. subtilis 10-4 (Bs) на активность аскорбатпероксидазы (APX) (A) и глутатион-редуктазы (GR) (Б) в проростках яровой пшеницы сортов Экада 70 (степной Волжский экотип, засухоустойчивый сорт) и Салават Юлаев (лесостепной западносибирский экотип, засуховосприимчивый сорт) в норме (Control) и при засухе (PEG).

Таким образом, полученные результаты свидетельствуют об эффрективности применения эндофитных бактерий $B$. subtilis 10-4 с целью повышения засухоустойчивости растений мягкой яровой пшеницы разных экотипов с наиболее выраженным защитным эффектом на растениях сорта Экада70 (степной Волжский экотип), что связано со способностью этих бактерий поддерживать целостность мембранных структур, а также регулировать состояние компонентов AsA-GSH комплекса и активность связанных с ними ферментов.

Работа выполнена частично при фринансовой поддержке Российского Фонда Фундаментальных Исследований (номер проекта 19-016-00035) и частично в рамках гос. задания (номер гос. регистрации АAАA-A21-121011990120-7) с использованием оборудования ЦКП «Агидель» и УНУ «Кодинк» УФИЦ РАН. 


\title{
Литература
}

1. FAO (2016) Available online: http://www.fao.org/3/a-i6030e.pdf (2016)

2. Lastochkina O., Aliniaeifard S., Kalhor M.S., Yuldashev R., Pusenkova L., Garipova S. Plant growth promoting bacteria - biotic strategy to cope with abiotic stresses in wheat. In: Wheat production in changing environments: Management, adaptation and tolerance / $\mathrm{M}$. Hasanuzzaman, K. Nahar, A. Hossain (eds.). Singapore. Springer. 2019. P. 579-614.

3. Sood G., Kaushal R., Sharma M. Significance of Inoculation with Bacillus subtilis to Alleviate Drought Stress in Wheat (Triticum aestivum L.) // Vegetos, 2020. V. 33. P. 782-792.

4. Lastochkina O., Garshina D., Ivanov S., Yuldashev R., Khafizova R., Allagulova Ch., Fedorova K., Avalbaev A., Maslennikova D., Bosacchi M. Seed Priming with Endophytic Bacillus subtilis Modulates Physiological Responses of Two Different Triticum aestivum L. Cultivars Under Drought Stress // Plants. 2020. V. 9. № $12 . \quad$ P. 1810 (https://doi.org/10.3390/plants9121810)

5. Bindschedler L. V., Minibaeva F., Gardner S. L., Gerrish C., Davies D. R., Bolwell G. P. Early Signalling Events in the Apoplastic Oxidative Burst in Suspension Cultured French Bean Cells Involve cAMP and Ca2+ // New Phytol. 2001. V. 151. № 1. P. 185-194.

6. Heath R. L., Packer L. Photoperoxidation in Isolated Chloroplasts. Kinetics and Stoichiometry of Fatty Acid Peroxidation // Archives Biochem. Biophysic. 1968. V. 125. P. 189-198.

7. Maslennikova D. R., Plotnikov A. A., Shakirova F. M. Comparative Analysis of the Physiological Effect of Nitric Oxide and 6-benzylaminopurine on the Components of the Glutathione Complex in the Roots of Wheat Seedlings // Agrokhimiya. 2019. № 3. P. 37. https://doi10.1134/S0002188119030104

\section{Induction of drought tolerance in Triticum aestivum L. (wheat) plants of different agroecological groups by endophytic bacteria Bacillus subtilis}

\author{
O. V. Lastochkina**, D. R. Maslennikova ${ }^{1}$, D. Y. Garshina ${ }^{2}$ \\ ${ }^{1}$ Institute of Biochemistry and Genetics UFRC RAS \\ 71 Prospekt Oktyabrya, 450054 Ufa, Republic of Bashkortostan, Russia. \\ ${ }^{2}$ Bashkir Research Institute of Agriculture UFRC RAS \\ 19 Richard Zorge Street, 450059 Ufa, Republic of Bashkortostan, Russia. \\ *Email: oksanaibg@gmail.com
}

It has been established that an important contribution in endophytic bacteria $B$. subtilis 10-4caused adaptation and drought tolerance of wheat plants - representatives of the steppe Volga (cv. Ekada70) and the forest-steppe West Siberian (cv. Salavat Yulaev) ecotypes is made by the ability of these bacteria to regulate the components of AsA-GSH complex and stabilize the oxidative status in plant cells under stress.

Keywords: Triticum aestivum L., ecotypes, drought, endophytic bacteria, Bacillus subtilis, plant-microbe interactions, $\mathrm{H}_{2} \mathrm{O}_{2}$, MDA, AsA-GSH complex, induced tolerance. 